\title{
Cyanotoxin release from the benthic, mat-forming cyanobacterium Microseira (Lyngbya) wollei in the St. Lawrence River, Canada
}

\author{
Sylvie Poirier-Larabie ${ }^{1} \cdot$ Christiane Hudon $^{1} \cdot$ Hugo-Pierre Poirier Richard ${ }^{1} \cdot$ Christian Gagnon $^{1}$ (D)
}

Received: 20 September 2019 / Accepted: 13 May 2020 / Published online: 26 May 2020

(C) The Author(s) 2020

\begin{abstract}
Benthic cyanobacterial mats occurring in the St. Lawrence River fluvial lakes Saint-Louis and Saint-Pierre are dominated by Microseira (Lyngbya) wollei which produce several cyanotoxins including LWTX-1 that is characteristic of Microseira wollei. This cyanotoxin is not only present in the filaments forming benthic mats, but was also measured in the water overlying the mats. LWTX-1 was found in all cyanobacterial filament samples (75.29-103.26 ng mg ${ }^{-1}$ ) and all overlying water samples (3.01$\left.11.03 \mathrm{ng} \mathrm{L}^{-1}\right)$. Toxin concentrations measured in overlying water and dry biomass were strongly correlated $(r=0.94)$. Furthermore, LWTX-1 concentration in water was positively correlated with the dissolved organic carbon in water $(r=0.74)$ and $\%$ nitrogen content in cyanobacterial filaments $(r=0.52)$. A preliminary study was conducted to determine the release and degradation rates of LWTX-1 from a $M$. wollei mat kept under laboratory conditions over a 3-month period. Toxin measurements revealed an early, massive toxin release followed by a typical decaying function, with a half-life in the order of 17 days. Our results raise concerns about the occurrence and downstream advection of dissolved cyanotoxins from Microseira mats in the aquatic environment.
\end{abstract}

Keywords Cyanotoxin release $\cdot$ Microseira $($ Lyngbya) wollei $\cdot$ Mass spectrometry $\cdot$ Benthic cyanobacterial mat

\section{Introduction}

Harmful algal blooms (HABs) of benthic cyanobacteria mats of Microseira (formerly Lyngbya) wollei (Farlow ex Gomont) G.B.McGregor \& Sendall ex Kenins (Guiry and Guiry 2014; Kenins 2017) have been observed for several years in freshwaters around the globe (Onodera et al. 1997; Foss et al. 2012; Hudon et al. 2016; Smith et al. 2019). Causes of proliferation include eutrophication resulting from human activities, warming water temperatures, global warming (Paerl and Huisman 2009; O'Neil et al. 2012; Paerl and Paul 2012; Paerl et al. 2016; Visser et al. 2016), and qualitative and quantitative load of nutrients near watersheds and airsheds (O'Neil et al. 2012; Paerl et al. 2016). Cyanotoxins from benthic cyanobacteria mats of Microseira wollei have been characterized for molecular structures and environmental

Responsible Editor: Vitor Manuel Oliveira Vasconcelos

Christian Gagnon

Christian.gagnon@canada.ca

1 Environment and Climate Change Canada, 105 McGill, Montréal, Québec H2Y 2E7, Canada concentrations (Onodera et al. 1997; Seifert et al. 2007; Foss et al. 2012; Gaget et al. 2017; D'Agostino et al. 2019). They contain, among others, cyanotoxins of the paralytic shellfish poison (PSP) family as saxitoxin analogs (STX) such as mainly decarbamoylgonyautoxins $2 \& 3$ (dcGTX $2 \& 3$ ) and decarbamoylsaxitoxin (dcSTX), some other analogs, and microseira-specific LWTX 1-6 (Paerl and Huisman 2009). It may also produce cylindrospermopsin (CYN), deoxycylindrospermopsin (deoCYN), and some microcystins (O'Neil et al. 2012; Paerl et al. 2016). The toxicity of these cyanotoxins can vary widely. Indeed, as demonstrated by Onodera et al. (1997) and by Oshima (1995), the toxicity of STX, dcSTX, and dcGTX $2 \& 3$ is much higher (1617-2483 mouse unit (MU, $\left.\left.\mu \mathrm{mol}^{-1}\right)\right)$ than that of LWTX 1-6 $(<10$ $\left.326 \mathrm{MU}\left(\mu \mathrm{mol}^{-1}\right)\right)$. Also, these cyanotoxins demonstrate different types of toxicity such as neurotoxicity (saxitoxin), dermatotoxicity (LWTX-1), hepatotoxicity, and cytotoxicity (cylindrospermopsin) (Onodera et al. 1997; Roy-Lachapelle 2016).

For planktonic and benthic (including Microseira) cyanobacteria, the environmental factors controlling cyanotoxin production and release into the environment are still poorly unknown (Sivonen and Jones 1999). Planktonic 
cyanobacteria appear to produce the highest toxin concentrations under the light, temperature, and nutrient concentrations most favorable for their growth. In culture, the rate of microcystin production was directly proportional to population growth rate, no matter what environmental factor was limiting growth (Orr and Jones 1998): toxin concentrations rose during the period of active cell growth, reaching a maximum during or in the late logarithmic phase (Sivonen 1990). Cellular decay, death, and lysis of planktonic cyanobacteria lead to toxin release in the environment (Chorus and Bartram 1999), potentially leading to toxin assimilation by benthic macroinvertebrates (Umehara et al. 2017). As with planktonic cyanobacteria, toxin concentrations in Microseira (Lyngbya) wollei were positively correlated with in situ biomass and possibly to the physiological status of filaments (Hudon et al. 2016), although the mechanisms triggering toxin release in benthic cyanobacterial mats remain to be ascertained.

The large level of spatial (between and within fluvial lakes) and temporal (seasonal, inter-annual 2006-2013) variability in Microseira wollei biomass and LWTX-1 concentration in mats has been previously demonstrated in the St. Lawrence River (Hudon et al. 2016), raising the hypothesis that Microseira wollei could release cyanotoxins into the overlying waters in proportion with the biomass of benthic mats of filaments. As an insight, the wash water from cleaning up the sampled filament mats from detritus and sediment contained a thousand times more LWTX-1 (result not shown) than measured in samples from the water column. For this reason, it was hypothesized that even if the cyanobacterial mats were healthy, and not about to die and release its toxins by cell lysis, any disturbance of mats (such related to episodes of wind, waves, or current) could stimulate the release of toxins. The main mechanism of toxin release from Microseira wollei cells is unknown so far. There is some evidence that not only cell lysis is responsible for algal toxin release. Walls et al. (2018) demonstrated with microcystin sp. (both in laboratory and in situ) that temperature regulates the production of harmful cyanobacteria and the release of toxins. Several combinations of light and temperature conditions have shown impact on growth rate and influence on the production and release of cylindrospermopsin (Preußel et al. 2009).

LWTX-1 toxin (Fig. 1) is characteristic of the benthic cyanobacterial mats of Microseira wollei which predominate in the St. Lawrence River fluvial lakes (Lajeunesse et al. 2012; D'Agostino et al. 2019). This relatively mild toxin is not found in pelagic cyanobacteria (Onodera et al. 1997). It is therefore a good tracer of the benthic cyanobacteria mats of Microseira wollei and the release of this toxin in the water column could indicate its presence as well as the presence of the other associated cyanotoxins of this benthic algae (D'Agostino et al. 2019). Since a reference standard was available for this toxin, albeit not certified at the beginning of this study but became certified in 2018 by National Research
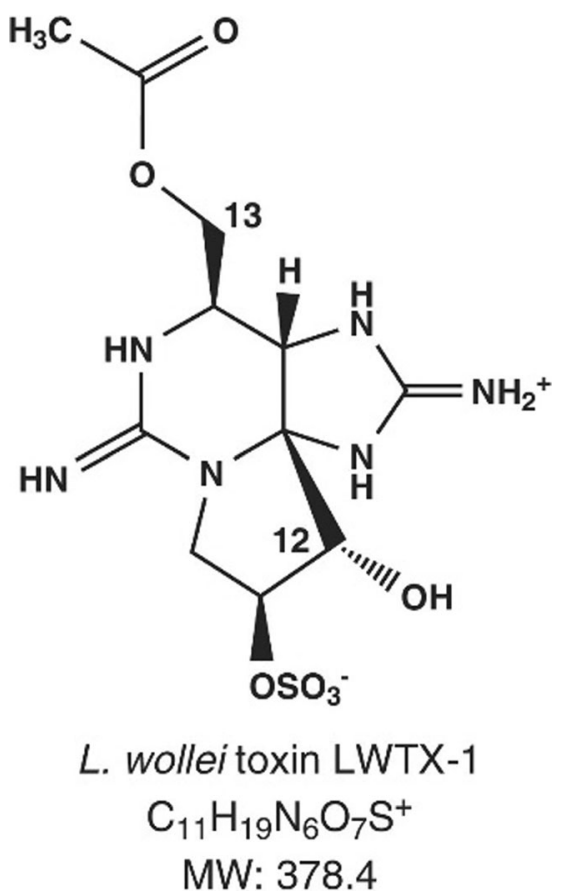

Fig. 1 Molecular structure of LWTX-1 toxin

Council Canada (NRC), LWTX-1 was therefore selected in order to study the release of toxins from algae mats in Lake Saint-Louis and Saint-Pierre.

Subsequently, the LWTX-1 toxin release rate and decay from a cyanobacterial mat kept under stable laboratory conditions were evaluated in order to estimate its persistence in the environment. The fate of some cyanobacterial metabolites released in water was reported (microcystins, nodularin, cylindrospermopsin) (Hiskia et al. 2014) but there is still a lack of data regarding the fate of LWTX-1. Detection and quantification of LWTX-1 released by cyanobacterial mats in the overlying water required the development of an extraction and purification method to reduce the matrix effect while concentrating the toxin to offset its dilution by river waters. The accurate measurement of released toxins requires the use of adequate analytical blanks, that are, waters unaffected by cyanobacteria, yet bearing a chemical signature similar enough to correct for the matrix effect. This challenge is particularly important in the St. Lawrence River, where Microseira wollei rarely occurs in waters originating from Lake Ontario but rather proliferates in shorewaters influenced by brown, nutrient-rich tributaries draining farmlands (Lévesque et al. 2017a). In Lake Saint-Louis, M. wollei is exclusively found in the Ottawa River waters flowing along the north shore, whereas in Lake Saint-Pierre, cyanobacterial mats are concentrated along the south shore, in waters influenced by the Yamaska and St. François rivers (Fig. 2). The choices of matrix blanks were therefore made considering the presence or absence of LWTX-1 and the physicochemical characteristics of the tributary upstream of the sampling site. 


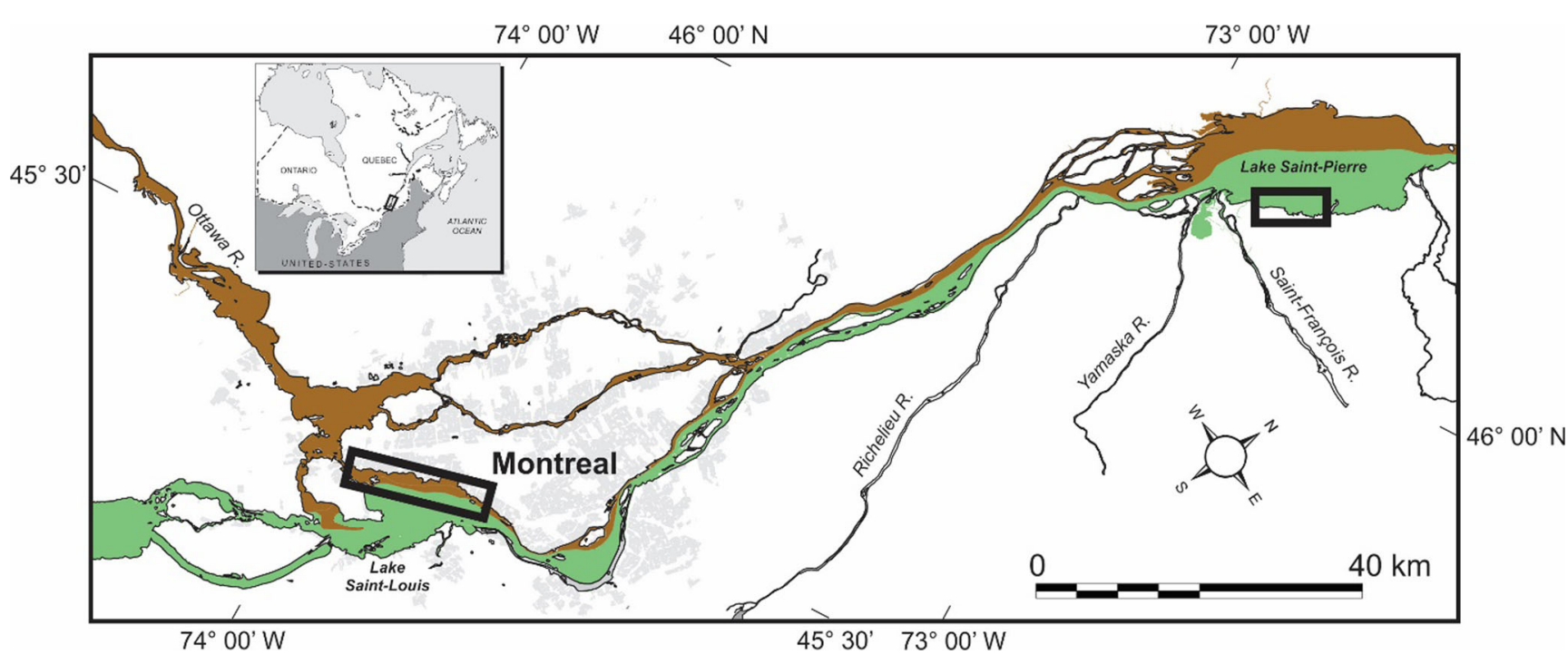

Fig. 2 Location of M. wollei sampling areas in fluvial lakes Saint-Louis and Saint-Pierre (rectangular boxes), St. Lawrence River (QC, Canada, see inset). Urbanized areas (in gray) and major tributaries are shown: waters from Great Lakes (green) and Ottawa River (brown)

\section{Material and methods}

\section{Material and standards}

Standard of cyanotoxins (LWTX-1) $(11 \mu \mathrm{M}$ in $17 \mu \mathrm{M}$ acetic acid) (not certified) was obtained from the Marine Analytical Chemistry Standard Program (NRC, Halifax, NS, Canada). Diluted LWTX-1 calibration solutions were prepared in acetic acid $(0.01 \mathrm{M})$ and stored at $-20^{\circ} \mathrm{C}$ in amber glass bottles. LCMS grade water $\left(\mathrm{H}_{2} \mathrm{O}\right)$, methanol $(\mathrm{MeOH})$, and acetonitrile $(\mathrm{ACN})$ were purchased from Fisher Scientific Canada (Ottawa, ON). Ammonium bicarbonate $\left(\mathrm{NH}_{4} \mathrm{HCO}_{3}\right)$, acetic acid $\left(\mathrm{CH}_{3} \mathrm{COOH}\right)$, ammonium formate $\left(\mathrm{NH}_{4} \mathrm{HCO}_{2}\right)$, formic acid $(\mathrm{HCOOH})$, and ammonium hydroxide $\left(\mathrm{NH}_{4} \mathrm{OH}\right)$ were purchased from Sigma-Aldrich Canada (Oakville, ON). Deionized water $\left(\mathrm{DI}-\mathrm{H}_{2} \mathrm{O}\right)$ passed through a Milli-Q Advantage A10 system (Millipore, Billerica, MA) was used for method blanks. This system is equipped with activated carbon, an ion exchange resin, and a UV lamp to reduce total organic carbon (TOC) to $\leq 5 \mathrm{ppb}$ and increase resistivity $(\geq$ $18.0 \mathrm{M} \Omega \mathrm{cm}$ ). Tap water treated with activated charcoal filter, $5-\mu \mathrm{m}$ particulate filter, and UV irradiation unit was used for the degradation of biomass mat in aquarium.

\section{Sample collection and preservation and characterization}

\section{Study sites}

Samples were collected in the shallow $(<3 \mathrm{~m})$, slow flowing $\left(<40 \mathrm{~cm} \mathrm{~s}^{-1}\right)$ littoral areas of fluvial lakes Saint-Louis and Saint-Pierre, which are enlargements (respectively 148 and $300 \mathrm{~km} 2$ ) of the St. Lawrence River (Fig. 2). Lake SaintLouis is located at the confluence with the Ottawa River, in the largely urbanized Montreal area. In contrast, Lake SaintPierre lies $65 \mathrm{~km}$ downstream, in a rural setting. Mean $( \pm \mathrm{SD})$ annual St. Lawrence River discharge at the outlet of Lake Saint-Louis was markedly higher in $2017(10,015 \pm$ $\left.1540 \mathrm{~m}^{3} \mathrm{~s}^{-1}\right)$ than the $2000-2016$ average $(8090 \pm$ $1013 \mathrm{~m} 3 \mathrm{~s}^{-1}$ ). In both fluvial lakes, waters originating from Lake Ontario flow in the central navigation channel, with little lateral mixing with waters from the Ottawa River (flowing along the north shore) and other tributaries.

\section{Field sampling}

Water samples and biomass of Microseira wollei were collected at the end of the summer in lakes Saint-Louis (15 August 2017, $N=4$ ) and Saint-Pierre (28 August 2017, $N=3$ ). Water samples for dissolved LWTX-1 measurements and for water quality analyses were pumped $15 \mathrm{~cm}$ above the cyanobacterial mat in pre-conditioned 1-L Nalgene polypropylene bottles. Water samples were kept on ice after sampling and subsequently stored at $-20{ }^{\circ} \mathrm{C}$ until LWTX-1 analysis. The biomass of Microseira wollei was collected using a $35-\mathrm{cm}$ wide double-headed rake dragged over a distance of about $1 \mathrm{~m}$ on the bottom (Yin et al. 2000) and was averaged from 3 strokes sampled around the boat.

\section{Characterization of water quality, cyanobacterial biomass, and condition}

Unfiltered water subsamples were used for analyses of suspended matter (SM), total phosphorus (TP), and total nitrogen (TN). Filtered water samples (Whatman $\mathrm{GF} / \mathrm{C}$ ) were analyzed for total dissolved phosphorus (TDP), $\mathrm{NO}_{2}-\mathrm{NO}_{3}$, $\mathrm{NH}_{4}{ }^{+}$, total dissolved nitrogen (TDN), dissolved organic carbon (DOC), and color (Platinum/Cobalt, $\mathrm{Pt} / \mathrm{Co}$ ) using 
standard methods (Quebec Laboratory of Environment Testing, Montréal 2011). After collection, mats of filamentous cyanobacteria and accompanying vascular macrophytes were rinsed with running water to eliminate sediments, debris, and invertebrates. Cleaned plant material was then sorted, identified microscopically, weighed, and frozen until drying. Biomass of cyanobacterial mats was largely comprised of Microseira wollei filaments ( $>95 \%$ ), with the occasional occurrence of (nontoxic) filamentous chlorophytes, epiphytic diatoms, and Heteroleibleinia. Wet biomass (WM) of M. wollei was converted to dry mass (DM) using a wet:dry conversion factor of 3.4:1 derived from paired measurements of wet and dry mass. Carbon and nitrogen content (as \% of $\mathrm{DM}$ ) of $M$. wollei filaments was determined on ground samples, using an elemental analyzer (Vario MACRO cube CHNS, Elementar, Germany) (Quebec Laboratory of Environment Testing, Montréal 2011); phosphorus content (as \% of DM) of filaments was determined following Stainton et al. (1977).

\section{Development and validation method: toxin analysis}

\section{LWTX-1 extraction}

LWTX-1 was extracted from cyanobacterial filaments using previously developed methodology (Lajeunesse et al. 2012). Extraction of LWTX-1 from water was carried out using the solid phase extraction (SPE) method, adapted from Onodera et al. and Zervou et al. (2017). Thermo Scientific HyperSep Hypercarb SPE cartridges were tested on a Vac Master Sample Processing Station (International Sorbent Technology $\left.{ }^{\circledR}\right)$ purchased from Biotage ${ }^{\circledR}$ (Charlotte, NC) for the extraction of the LWTX-1 analyte using $100 \mathrm{~mL}$ of river water. These cartridges contain $500 \mathrm{mg}$ of porous graphite carbon sorbent. Cartridges were conditioned by adding $6 \mathrm{~mL}$ of $\mathrm{MeOH}$ followed by $6 \mathrm{~mL} 100 \mathrm{mM} \mathrm{NH}_{4} \mathrm{HCO}_{3} \mathrm{pH} 10$. Sample $\mathrm{pH}$ was adjusted by adding $10 \mathrm{~mL}$ of $100 \mathrm{mM}$ $\mathrm{NH}_{4} \mathrm{HCO}_{3} \mathrm{pH} 10$ to $100 \mathrm{~mL}$ of water sample. Sample load flow rate was about $2-4 \mathrm{~mL} \mathrm{~min}^{-1}$. After sample loading, cartridges were washed with $6 \mathrm{~mL}$ of $\mathrm{MeOH}$. Analyte was eluted with $2 \times 3 \mathrm{~mL}$ of $\mathrm{MeOH} / 2 \%$ acetic acid. SPE extracts were collected in $10-\mathrm{mL}$ centrifuge tubes and evaporated to dryness under a gentle stream of nitrogen in a dry bath set at $40{ }^{\circ} \mathrm{C}$. Evaporated extracts were then reconstituted to $200 \mu \mathrm{L}$ with $0.1 \mathrm{M}$ acetic acid, vortexed for $10 \mathrm{~s}$, sonicated for $5 \mathrm{~min}$, and quickly centrifuged and transferred to $2-\mathrm{mL}$ glass vials for LC-QqQMS analysis.

\section{Identification and quantification of LWTX-1 using LC-QqQMS}

Toxins were analyzed in cyanobacterial filaments and water samples using a 1200 Series liquid chromatographer coupled to an electrospray triple-quadrupole mass spectrometer 6410
(Agilent, Santa Clara, CA). LC-MS/MS parameters are presented in Table 1. LC-MS/MS raw data obtained from LCQqQMS analysis of water samples were analyzed with the MassHunter quantitative software (Agilent, Santa Clara, CA). Two MRM transitions were selected for each analyte, precursor ion and two fragments ions, the first with higher signal for quantification and the second one for qualitative identification confirmation. The chromatography and mass spectrometry characteristics used were based on previously developed methodology (Lajeunesse et al. 2012). Briefly, the chromatographic separation was performed using an HILIC (hydrophilic interaction liquid chromatography) TSKgel Amide- 80 column $(3 \mu \mathrm{m}, 2 \times 150 \mathrm{~mm})$. The mobile phase was constituted of solvent $\mathrm{A}$ : aqueous $5 \mathrm{mM}$ $\mathrm{NH}_{4} \mathrm{OOCH}$ and $\mathrm{HCOOH} 3.6 \mathrm{mM}(\mathrm{pH}=3.5)$ and solvent $\mathrm{B}$ : $95 \% \mathrm{MeCN}-5 \%$ aqueous $5 \mathrm{mM} \mathrm{NH}_{4} \mathrm{OOCH}$ and $3.6 \mathrm{mM}$ $\mathrm{HCOOH}(\mathrm{pH}=3.5)$. The volume injected was $15 \mu \mathrm{L}$.

\section{Method validation}

Method validation for water extraction was performed by evaluating linearity, precision, accuracy, recovery, and lower limit of quantification. In order to take into account the matrix and its effects on the method, the validation was carried out in the St. Lawrence River surface waters used as a matrix blank. Since the two sampling sites are under the influence of two different water bodies, tributary waters sampled upstream of the areas colonized by $M$. wollei were used as matrix blanks for method development and validation in water. First, St. Lawrence River surface waters originating from Lake Ontario were used as matrix blanks for Lake Saint-Louis samples. Second, Yamaska River surface waters were used as matrix blanks for Lake Saint-Pierre samples. Every validation test was evaluated in those two matrices. Also, since a certified LWTX-1 standard was not available at the beginning of this study, and a noncertified standard was available but in limited quantity, an in-house reference material (RM) was prepared, as additional quality control, from a large batch of fieldcollected cyanobacterial filaments. A determined amount of freeze-dried, powdered filaments was weighted and mixed with $0.1 \mathrm{M}$ acetic acid prior to heating $\left(100{ }^{\circ} \mathrm{C}\right.$ for $5 \mathrm{~min}$ ). This mixture was quantitatively transferred to an amber bottle and the LWTX-1 concentration was quantified using a (noncertified) standard curve by serial dilutions of the filtered mix in $0.1 \mathrm{M}$ acetic acid.

\section{Linearity and limit of quantification}

The linearity was evaluated with linear regression on a 4point standard curve from 4 to $100 \mathrm{ng} \mathrm{L}^{-1}$ for each sampling site in water and from 3 to $30 \mathrm{ng} \mathrm{mg}^{-1}$ in cyanobacterial filaments. Quantification was done with 
Table 1 MS/MS acquisition parameters

\begin{tabular}{llllllll}
\hline Compound name & Prec ion & Prod ion & Dwell & Frag (V) & CE (V) & Delta EMV & Polarity \\
\hline LWTX-1 & 379.1 & 299.1 & 200 & 115 & 12 & 500 & Positive \\
LWTX-1 & 379.1 & 138.2 & 200 & 115 & 30 & 500 & Positive \\
\hline
\end{tabular}

Prec ion precursor ion; Prod ion product ion; Frag fragmentation voltage; CE collision energy; Delta EMV electron multiplication voltage standard curves in each matrix for the analyte based on the peak area versus the corresponding concentration.

\section{Precision and accuracy}

The precision was evaluated on triplicate analysis of matrix blank from each site, spiked with $10 \mu \mathrm{L}$ in-house reference material. The accuracy was evaluated on triplicate analyses, prepared as precision quality control, and fortified with noncertified standard at $10 \mathrm{ng} \mathrm{mL}^{-1}$. The accuracy was subtracted from the precision to obtain a value that was expected to represent the noncertified standard at $10 \mathrm{ng} \mathrm{mL}^{-1}$.

\section{Recovery}

The recovery was evaluated in an intraday experiment for each lake with spiked samples of matrix blank with standard and with treated tap water spiked with in-house reference material. The spiked calibration curve in surface river water and the treated tap water spiked with in-house reference material were compared with standard curve in solution. In addition, spiked field samples were compared with standard in solution. The recovery yield was calculated as follows:

Recovery $=\frac{\text { QC spiked before extraction }}{\text { Standard in solution }}$

Recovery in each sample

$=\frac{\text { Sample spiked before extraction }}{\text { Standard in solution }}$

\section{LWTX-1 release under laboratory conditions}

A preliminary study was conducted to determine the release and degradation rates of LWTX-1 from a $M$. wollei mat kept under laboratory conditions. Cyanobacteria collected from Lake Saint-Pierre were brought to the laboratory and maintained in an aquarium filled with $2 \mathrm{~L}$ of treated tap water (5- $\mu \mathrm{m}$-activated charcoal filter and UV irradiation, devoid of toxins, as verified by initial blank measurements) for 105 days at room temperature and low light intensity $(\approx$ $10 \mu \mathrm{mol} \mathrm{m} \mathrm{m}^{-2} \mathrm{~s}^{-1}$ ). A $100-\mathrm{mL}$ sample from overlying water was taken periodically with a graduated pipet and transferred into a $100-\mathrm{mL}$ polypropylene bottle and analyzed for LWTX-
1 using the same extraction procedure as water samples (see the "LWTX-1 extraction" section and the "Identification and quantification of LWTX-1 using LC-QqQMS" section).

\section{Statistical analyses}

Relationships between LWTX-1 concentrations and physical, chemical, and biological variables were examined using linear regressions and Pearson $r$ correlation coefficient (Excel). The decaying function of toxins released by the cyanobacterial mat kept under laboratory conditions was modeled using an exponential regression (Excel).

\section{Results}

\section{Validation of LWTX-1 extraction method in water and filaments}

Validation of the LWTX-1 method for cyanobacterial filaments was carried out previously (Lajeunesse et al. 2012). In the present study, linearity, precision, accuracy, recovery, and lower limit of quantification were evaluated to validate the extraction method developed for LWTX-1 in water. As explained in the "Method validation" section, two different matrix blanks were used to account for the different matrix effects of each tributary. St. Lawrence River surface water originating from Lake Ontario was used for Lake Saint-Louis samples and Yamaska River surface water was used for Lake SaintPierre samples. As expected, the matrix effect differed among water sources, with waters originating from Lake Ontario showing the smallest matrix effect.

Linearity was evaluated with linear regression in each matrix blank and coefficients of determination $\left(R^{2}\right)$ equalled 0.999 for Lake Saint-Louis and 0.997 for Lake Saint-Pierre in water. Lower limit of quantification (LLOQ) was evaluated for accuracy for each lake, that is, $103.9 \%$ for Lake SaintLouis and $106.4 \%$ for Lake Saint-Pierre in water.

Precision was evaluated with in-house reference material spiked in each matrix blank. First, to evaluate the in-house reference material, a series of dilutions quantified on a standard curve in solution was carried out. The LWTX-1 concentration of in-house reference material equaled $57.6 \pm$ $2.7 \mathrm{ng} \mathrm{mg}^{-1}$. Then, precision evaluation varies with collection 
site, yielding more variations in Lake Saint-Louis (27\%) than in Lake Saint-Pierre (2\%). Accuracy was assessed as the difference between accuracy results (matrix blank spiked with $10 \mu \mathrm{L}$ in-house reference material and $10 \mathrm{ng} \mathrm{mL}^{-1}$ standard) and precision results (matrix blank spiked with $10 \mu \mathrm{L}$ inhouse reference material) in order to obtain the representation of the spiked standard in matrix with filament, as described in the "Method validation" section. Accuracy yielded similar results for both lakes, that is, 105\% for Lake Saint-Louis and $89 \%$ for Lake Saint-Pierre.

The recovery success was evaluated in an intraday experiment for both sites, using spiked samples and reference material. The spiked calibration curve in each matrix blank was compared with standard curve in solution, which resulted in recovery rates of $72 \%$ for Lake Saint-Louis and $50 \%$ for Lake Saint-Pierre. Also, spiked dechlorinated water with in-house reference material was compared with standard curve in solution which yielded a recovery rate of $96 \%$. In addition, spiked field samples were compared with standard in solution, which resulted in recovery rates of $46 \%$ in Lake Saint-Louis and $55 \%$ in Lake Saint-Pierre.

Repeated measurements of in-house reference material as additional quality control carried out during the analytical sequences of water samples closely matched the initial measurement for samples from both Lake Saint-Louis (60.47 \pm $\left.10.27 \mathrm{ng} \mathrm{mg}^{-1}\right)$ and Lake Saint-Pierre $\left(61.23 \pm 1.45 \mathrm{ng} \mathrm{mg}^{-1}\right)$.

\section{Relationship between toxin concentrations in water and filaments}

Biomass of filament sampled at each lake ranged from 3 to $12 \mathrm{~g} \mathrm{DM} \mathrm{m}^{2-1}$ for Lake Saint-Louis and 2.6 to $139.8 \mathrm{~g} \mathrm{DM} \mathrm{m}^{2-1}$ for Lake Saint-Pierre; on average, biomass was 10-fold higher for Lake Saint-Pierre than Lake SaintLouis. LWTX-1 was quantified in all samples and ranged from 3.01 to $11.03 \mathrm{ng} \mathrm{L}^{-1}$ in water samples and from 75.29 to $103.26 \mathrm{ng} \mathrm{mg}^{-1}$ in filament samples for Lake Saint-Louis and from 31.14 to $93.13 \mathrm{ng} \mathrm{L}^{-1}$ in water samples and from 201.99 to $393.64 \mathrm{ng} \mathrm{mg}^{-1}$ in filament samples for Lake SaintPierre. Higher LWTX-1 concentrations were observed in Lake Saint-Pierre, both in filaments (by 3-fold) and in the water (by 10 -fold) overlying cyanobacterial mats. As hypothesized, LWTX-1 concentration in water was positively correlated $(r=0.94, p=0.0008)$ with cyanobacterial mat biomass (Fig. 3a). A clear trend was observed between LWTX-1 concentration in water and toxin concentration in the cyanobacterial filaments $(r=0.10$, n.s., Fig. $3 b)$.

\section{Relationships between toxin concentrations and environmental conditions}

Physical and chemical water quality characteristics were remarkably similar between Lake Saint-Louis and Lake Saint-
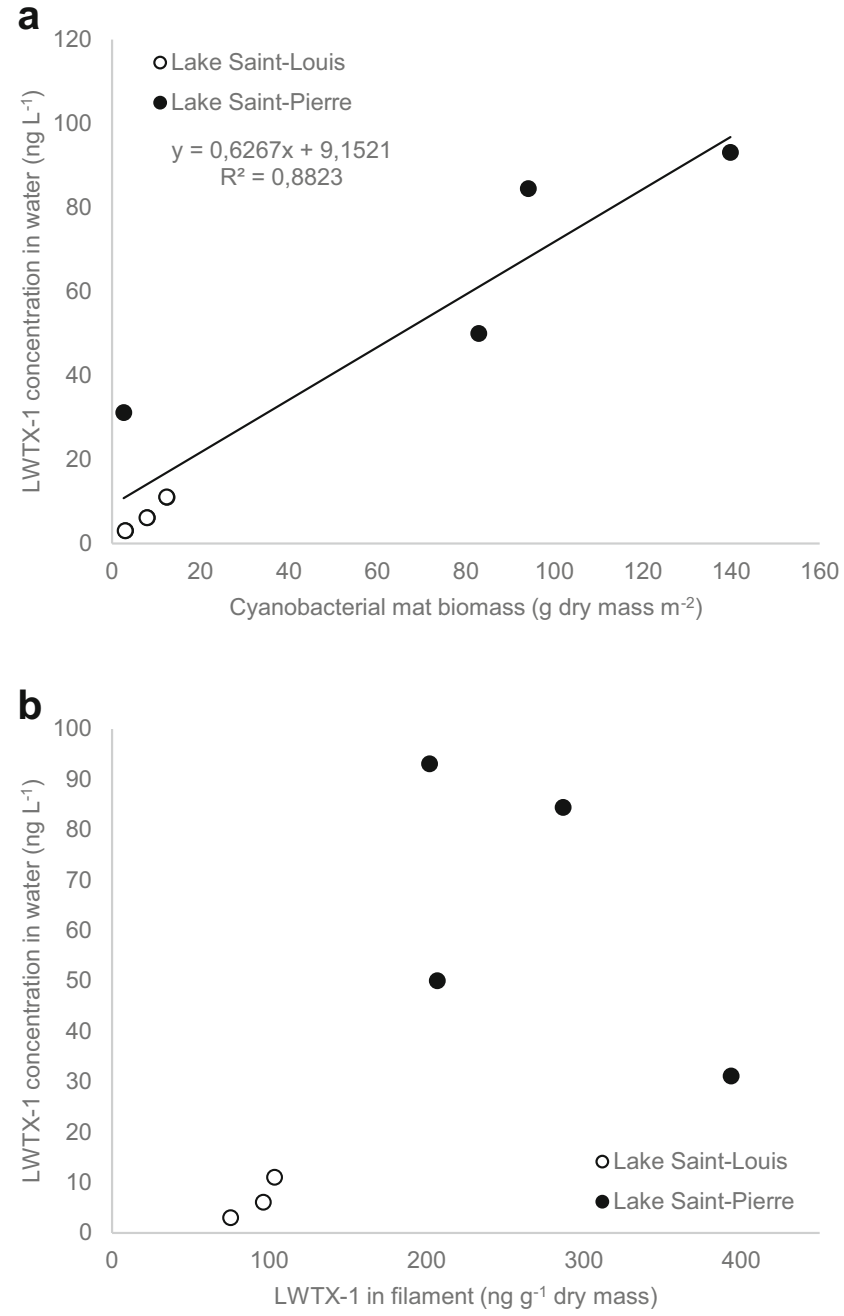

Fig. 3 Relationship between LWTX-1 concentration in water and a M. wollei biomass and b LWTX-1 in cyanobacterial filaments

Pierre in August 2017 (Table 2). Cyanobacterial mats were growing in $2 \mathrm{~m}$ of water, with near-bottom Secchi depth owing to low $\left(<5 \mathrm{mg} \mathrm{L}^{-1}\right)$ suspended matter concentrations but DOC-rich $\left(>6 \mathrm{mg} \mathrm{C} \mathrm{L}^{-1}\right)$ colored waters $(>30 \mathrm{Pt} / \mathrm{Co})$. Both sites exhibited moderate enrichment by phosphorus $(\mathrm{TP}<$ $\left.20 \mu \mathrm{g} \mathrm{P} \mathrm{L}^{-1}\right)$ and nitrogen $\left(\mathrm{TN}<600 \mu \mathrm{g} \mathrm{N} \mathrm{L}^{-1}\right)$, but low $(<$ $200 \mu \mathrm{g} \mathrm{N} \mathrm{L}^{-1}$ ) nitrite-nitrate concentrations. Data combined for both study sites revealed that LWTX-1 concentration in water was positively correlated with concentration of dissolved organic carbon $(r=0.74, p=0.03$, Fig. $4 \mathrm{a})$ and weakly with $\%$ nitrogen content in the cyanobacterial filaments $(r=$ $0.52, p=0.11$, Fig. $4 b$ ).

\section{Toxin release and degradation rate}

Assays of toxin release and degradation were conducted by measuring LWTX-1 concentrations in water overlying a cyanobacterial mat kept under controlled laboratory conditions (Fig. 5). In the first week, an increase up to 
Table 2 Comparison of physical and chemical characteristics (mean $\pm \mathrm{SD}$ ) measured at the time of cyanobacterial mat sampling in Lake Saint-Louis $(N=3,15$ August 2017) and Lake SaintPierre $(N=4)$ (28 August 2017)

\begin{tabular}{lll}
\hline & Lake Saint-Louis & Lake Saint-Pierre \\
\hline Sample depth $(\mathrm{m})$ & $2.03 \pm 0.25$ & $1.90 \pm 0.34$ \\
Conductivity $\left(\mu \mathrm{S} \mathrm{cm}^{-1}\right)$ & $200.6 \pm 46.6$ & $241.7 \pm 12.7$ \\
Suspended matter $\left(\mathrm{mg} \mathrm{L}^{-1}\right)$ & $4.0 \pm 1.7$ & $1.5 \pm 0.6$ \\
Color $(\mathrm{Pt} / \mathrm{Co})$ & $34.7 \pm 11.7$ & $32.0 \pm 3.6$ \\
Secchi depth $(\mathrm{m})$ & $1.9 \pm 0.1$ & $1.8 \pm 0.1$ \\
Dissolved organic carbon $\left(\mathrm{mg} \mathrm{C} \mathrm{L}^{-1}\right)$ & $6.2 \pm 0.9$ & $7.1 \pm 0.3$ \\
Total phosphorus $\left(\mu \mathrm{g} \mathrm{P} \mathrm{L}^{-1}\right)$ & $20 \pm 5$ & $17 \pm 3$ \\
Total dissolved phosphorus $\left(\mu \mathrm{g} \mathrm{P} \mathrm{L}^{-1}\right)$ & $13 \pm 1$ & $11 \pm 3$ \\
Total nitrogen $\left(\mu \mathrm{g} \mathrm{N} \mathrm{L}{ }^{-1}\right)$ & $570 \pm 26$ & $583 \pm 120$ \\
Total dissolved nitrogen $\left(\mu \mathrm{g} \mathrm{N} \mathrm{L}^{-1}\right)$ & $500 \pm 17$ & $533 \pm 113$ \\
Nitrites-nitrates $\left(\mu \mathrm{g} \mathrm{N} \mathrm{L}^{-1}\right)$ & $144 \pm 21$ & $166 \pm 104$ \\
Ammonium $\left(\mu \mathrm{N} \mathrm{L} \mathrm{L}^{-1}\right)$ & $5 \pm 6$ & $1.5 \pm 0$ \\
\hline
\end{tabular}

$26 \mathrm{ng} \mathrm{mL}^{-1}$ was observed and then concentrations dropped to near zero $\left(0.49 \mathrm{mg} \mathrm{mL}^{-1}\right)$ on day 105 , following a typical decaying curve. This indicated that toxins were mostly

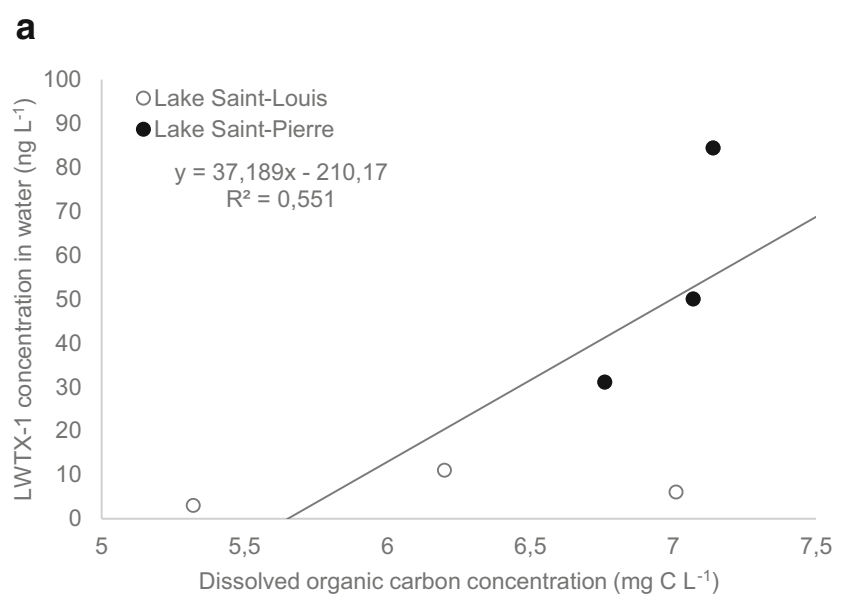

b

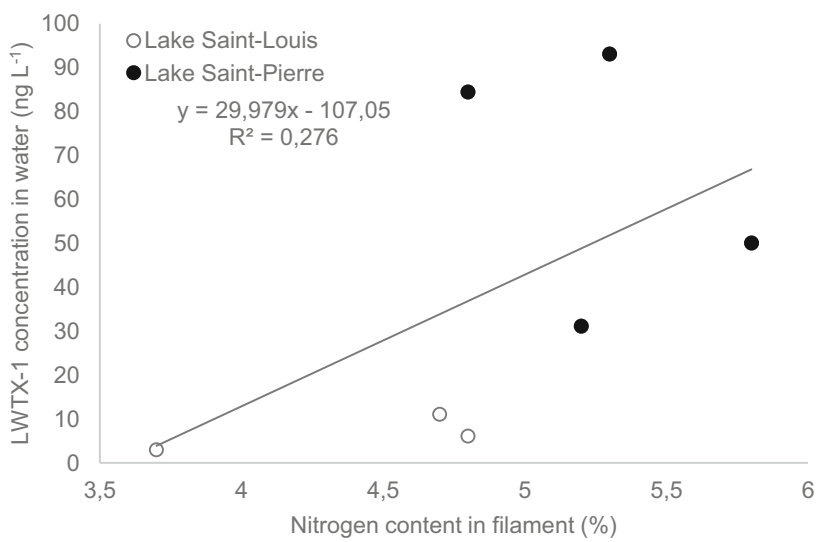

Fig. 4 Relationships between LWTX-1 concentration in water and a dissolved organic carbon concentration and $\mathbf{b}$ nitrogen content in cyanobacterial filaments released in the first week and then degraded over a period of almost 100 days. Over the same period, the color of the cyanobacterial mat slowly faded away and whitened over time. From this simple experiment, the half-life value of LWTX-1 was estimated at roughly 17 days at room temperature. Hiskia et al. (2014) reported that some transformation pathways may contribute to water detoxification from cyanotoxins: temperature and $\mathrm{pH}$-dependent decomposition, biological degradation, photolysis and photosensitized degradation.

\section{Discussion}

Our study took advantage of the wide range of $M$. wollei biomass sampled in 2017 in lakes Saint-Louis and Saint-Pierre (2.6-140 $\mathrm{g} \mathrm{DM} \mathrm{m}^{-2}$ ) to assess the importance of toxin release from the cyanobacterial mats into the overlying waters. Earlier records in the St. Lawrence have shown a large level of variability of $M$. wollei biomass on a spatial (within and among

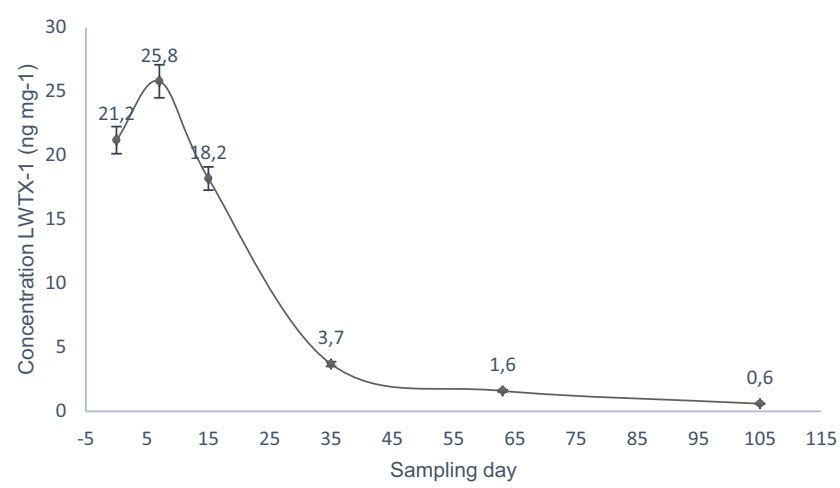

Fig. 5 Rate of LWTX-1 release and degradation from a M. wollei mat maintained under controlled laboratory conditions over a $105-\mathrm{d}$ period 
lakes) and a temporal (seasonally and among years) bases (Hudon et al. 2014, 2016).

The large variations of discharge and current speed prevailing in the St. Lawrence River are in sharp contrast with the hydrological stability of lakes (Smith et al. 2019) and springs (Pinowska et al. 2007) in which M. wollei is often found. This element brings forward the challenge of tracing the origin and advection of water masses into which toxins have been released by a cyanobacterial mat. Furthermore, current speed will determine the distance at which toxins will be advected downstream, possibly reaching drinking water intakes or recreational areas. The wind also likely exerts an influence on the release of toxins, as was shown by the strong disrupting effect of waves on cyanobacterial mats, and eventually throwing mats ashore (Lévesque et al. 2015).

The presence of water masses of different chemical signature (Table 2) flowing side by side with little lateral mixing further highlights the question of adequately identifying the water body to use as a matrix blank for toxin extraction and analysis. Since no labeled internal standard was available for LWTX-1 analysis, several precautions were taken to ensure the quality of the results. Appropriate water blanks bearing similar physicochemical properties and without toxins were sometimes difficult to find upstream of the sampling sites. Since matrix effects have a tremendous impact on results in LC-MS/MS analyses, additional quality controls were carried out with surface water samples spiked with either standard or in-house reference materials, from which accuracy reached $\geq$ $89 \%$ for each lake.

LWTX-1 concentrations measured in cyanobacterial filaments in the present (2017) study (75.29-103.26 $\mathrm{gg} \mathrm{g}^{-1}$ in LSL and 201.99-393.64 $\mu \mathrm{g} \mathrm{g}^{-1}$ in LSP) were higher than those previously reported in Lake Saint-Louis (51 \pm $40 \mathrm{\mu g} \mathrm{g}^{-1}$ 2007, 2009-2011) and in Lake Saint-Pierre (25 \pm $31 \mathrm{\mu g} \mathrm{g}^{-1}, 2006-2008,2012-2013$ ) (Hudon et al. 2016). The 10 -fold increase in toxin concentration in LSP was unexpected, given that this lake previously exhibited the lowest mat biomass and toxin concentrations. Results from this study however confirmed previous observations of positive correlations between LWTX-1 in filaments with ambient DOC and a weaker correlation with the $\%$ nitrogen content in the filaments, an indicator of filaments' health conditions (Hudon et al. 2016).

Our field results show that LWTX-1 toxin occurs in significant amounts in the water above Microseira wollei mats, ranging from 3.01 to $11.03 \mathrm{ng} \mathrm{L}^{-1}$ in Lake Saint-Louis and from 31.14 to $93.13 \mathrm{ng} \mathrm{L}^{-1}$ in Lake Saint-Pierre. Cyanobacterial mat biomass was positively correlated with LWTX-1 concentrations in the water overlying the mats. Surprisingly, weak correlation was found between toxin concentration in filaments and water. This could be due to many factors, such as current speed, the physiological status of mats, and sampling position above the biomass mat relative to the river current. In contrast with results from the present study, healthy (planktonic) cyanobacterial populations blooming in the field were reported to produce little extracellular toxin (Chorus and Bartram 1999). For planktonic blooms, cellbound concentrations were several orders of magnitude higher than toxins released in the water during bloom breakdown, owing to high dilution rate into ambient water (Jones and Orr 1994).

The conditions under which our laboratory experiment was conducted were coherent with the previously documented ability of $M$. wollei to survive under low light intensity (22$50 \mu \mathrm{mol} \mathrm{m}{ }^{-2} \mathrm{~s}^{-1}$ ) (Pinowska et al. 2007). Mats collected in the field were growing under low light intensity, as shown by the depth of collection $(2 \mathrm{~m})$ which was just below the Secchi depth, as previously observed in the St. Lawrence (Lévesque et al. 2012, 2017b). These observations support the general tendency for $M$. wollei to grow under low light intensity, in brown, DOC-rich waters with low inorganic nitrogen (Lévesque et al. 2012, 2017a). In addition, the sharp release of LWTX-1 within the first 7 days under laboratory conditions and the persistence of the toxin for over 100 days raise concerns about its occurrence in the raw waters of drinking water filtration plants. Release of cylindrospermopsin by benthic cyanobacteria contaminated drinking water in Australian reservoirs (Gregor et al. 2007; Zamyadi et al. 2012; Gaget et al. 2017; Lorenzi et al. 2018; Almuhtaram et al. 2018), but such occurrence has been more frequently documented with planktonic cyanobacteria (Gregor et al. 2007; Zamyadi et al. 2012; Almuhtaram et al. 2018).

\section{Conclusion}

This study provided a strong support to our hypothesis that Microseira wollei released cyanotoxins into the overlying waters in proportion with the biomass of mats of cyanobacterial filaments lying on the bottom. Accurate measurements of released toxins were made possible by the development of validation methods correcting for complex matrix effects resulting from the presence of variable/high DOC concentrations. LWTX-1 concentrations in the water overlying cyanobacterial mats were also correlated with ambient DOC and nitrogen content of the filaments, in agreement with earlier findings. Maintenance of mats under controlled laboratory conditions showed that the rate of LWTX-1 release was highest within the first week of sampling and followed a typical decaying curve over the next 100 days. These results emphasize the need for efficient monitoring of $M$. wollei proliferation in natural waters, to ensure environmental and public health and safety.

Acknowledgments The authors gratefully acknowledge Conrad Beauvais for the help with the field, Audrey Roy-Lachapelle for the 
sampling, and Maude Lachapelle for the laboratory analyses of plants. We thank Pierre Gagnon for the statistical analyses and François Boudreault for drafting the map. Water quality analyses were performed by the Laboratoire des Essais Environnementaux du Québec (LEEQECCC).

Author contributions Sylvie Poirier-Larabie, Christiane Hudon, and Christian Gagnon carried out conceptualization and sample design. Sylvie Poirier-Larabie and Hugo-Pierre Poirier Richard analyzed toxins. Christian Gagnon, Sylvie Poirier Larabie, and Christiane Hudon performed sample collection. Sylvie Poirier Larabie, Christian Gagnon, Christiane Hudon, and Hugo-Pierre Poirier Richard performed manuscript preparation, editing, and revision.

Funding information This work was supported by Environment and Climate Change Canada as a contribution to the Algal Blooms, Treatment, Risk Assessment, Prediction and Prevention through Genomics (ATRAPP) and the Canada-Québec St. Lawrence Action Plan (SLAP) Programs.

\section{Compliance with ethical standards}

Conflict of interest The authors declare that they have no conflict of interest.

Open Access This article is licensed under a Creative Commons Attribution 4.0 International License, which permits use, sharing, adaptation, distribution and reproduction in any medium or format, as long as you give appropriate credit to the original author(s) and the source, provide a link to the Creative Commons licence, and indicate if changes were made. The images or other third party material in this article are included in the article's Creative Commons licence, unless indicated otherwise in a credit line to the material. If material is not included in the article's Creative Commons licence and your intended use is not permitted by statutory regulation or exceeds the permitted use, you will need to obtain permission directly from the copyright holder. To view a copy of this licence, visit http://creativecommons.org/licenses/by/4.0/.

\section{References}

Almuhtaram H, Cui Y, Zamyadi A, Hofmann R (2018) Cyanotoxins and cyanobacteria cell accumulations in drinking water treatment plants with a low risk of bloom formation at the source. Toxins 10:430. https://doi.org/10.3390/toxins10110430

Chorus I, Bartram J (1999) Toxic cyanobacteria in water: a guide to their public health consequences, monitoring and management. World Health Organization. https://apps.who.int/iris/handle/10665/42827

D'Agostino PM, Boundy MJ, Harwood TD et al (2019) Re-evaluation of paralytic shellfish toxin profiles in cyanobacteria using hydrophilic interaction liquid chromatography-tandem mass spectrometry. Toxicon 158:1-7. https://doi.org/10.1016/j.toxicon.2018.11.301

Foss AJ, Phlips EJ, Yilmaz M, Chapman A (2012) Characterization of paralytic shellfish toxins from Lyngbya wollei dominated mats collected from two Florida springs. Harmful Algae 16:98-107. https:// doi.org/10.1016/j.hal.2012.02.004

Gaget V, Humpage AR, Huang Q, Monis P, Brookes JD (2017) Benthic cyanobacteria: a source of cylindrospermopsin and microcystin in Australian drinking water reservoirs. Water Res 124:454-464. https://doi.org/10.1016/j.watres.2017.07.073

Gregor J, Maršálek B, Šípková H (2007) Detection and estimation of potentially toxic cyanobacteria in raw water at the drinking water treatment plant by in vivo fluorescence method. Water Res 41:228 234. https://doi.org/10.1016/j.watres.2006.08.011

Guiry MD, Guiry GM (2014) AlgaeBase: an on-line resource for algae. Cryptogam Algol 35:105-115

Hiskia A, Triantis TM, Antoniou MG, de la Cruz AA, O'Shea K, Song W, Fotiou T, Kaloudis T, He X, Andersen J, Dionysiou DD (2014) Transformation products of hazardous cyanobacterial metabolites in water. In: Transformation products of emerging contaminants in the environment. John Wiley and Som pp 675-708. https:// onlinelibrary.wiley.com/doi/abs/10.1002/9781118339558.ch23

Hudon C, Sève MD, Cattaneo A (2014) Increasing occurrence of the benthic filamentous cyanobacterium Lyngbya wollei: a symptom of freshwater ecosystem degradation. Freshwater Science 33:606618. https://doi.org/10.1086/675932

Hudon C, Gagnon P, Poirier Larabie S, Gagnon C, Lajeunesse A, Lachapelle M, Quilliam MA (2016) Spatial and temporal variations of a saxitoxin analogue (LWTX-1) in Lyngbya wollei (cyanobacteria) mats in the St. Lawrence River (Québec, Canada). Harmful Algae 57:69-77. https://doi.org/10.1016/j.hal.2016.06.001

Jones GJ, Orr PT (1994) Release and degradation of microcystin following algicide treatment of a Microcystis aeruginosa bloom in a recreational lake, as determined by HPLC and protein phosphatase inhibition assay. Water Res 28:871-876. https://doi.org/10.1016/00431354(94)90093-0

Kenins A (2017) Validation of the noxious cyanophyte Microseira wollei (Farlow ex Gomont). Notulae algarum No 43. 3. ISSN: 2009-8987

Lajeunesse A, Segura PA, Gélinas M, Hudon C, Thomas K, Quilliam MA, Gagnon C (2012) Detection and confirmation of saxitoxin analogues in freshwater benthic Lyngbya wollei algae collected in the St. Lawrence River (Canada) by liquid chromatography-tandem mass spectrometry. J Chromatogr A 1219:93-103. https://doi.org/ 10.1016/j.chroma.2011.10.092

Lévesque D, Cattaneo A, Hudon C, Gagnon P (2012) Predicting the risk of proliferation of the benthic cyanobacterium Lyngbya wollei in the St. Lawrence River. Can J Fish Aquat Sci 69:1585-1595. https:// doi.org/10.1139/f2012-087

Lévesque D, Hudon C, Amyot J-P, Cattaneo A (2015) Wave exposure and current regulate biomass accumulation of the benthic cyanobacterium Lyngbya wollei in a large fluvial lake. Freshwater Science 34:867-880. https://doi.org/10.1086/682007

Lévesque D, Cattaneo A, Deschamps G, Hudon C (2017a) In the eye of the beholder: assessing the water quality of shoreline parks around the Island of Montreal through citizen science. Sci Total Environ 579:978-988. https://doi.org/10.1016/j.scitotenv.2016.10.175

Lévesque D, Hudon C, James PMA, Legendre P (2017b) Environmental factors structuring benthic primary producers at different spatial scales in the St. Lawrence River (Canada). Aquat Sci 79:345-356. https://doi.org/10.1007/s00027-016-0501-4

Lorenzi AS, Cordeiro-Araújo MK, Chia MA, do Carmo BittencourtOliveira M (2018) Cyanotoxin contamination of semiarid drinking water supply reservoirs. Environ Earth Sci 77:595. https://doi.org/ 10.1007/s12665-018-7774-y

O'Neil JM, Davis TW, Burford MA, Gobler CJ (2012) The rise of harmful cyanobacteria blooms: the potential roles of eutrophication and climate change. Harmful Algae 14:313-334. https://doi.org/10. 1016/j.hal.2011.10.027

Onodera H, Satake M, Oshima Y, Yasumoto T, Carmichael WW (1997) New saxitoxin analogues from the freshwater filamentous cyanobacterium Lyngbya wollei. Nat Toxins 5:146-151. https://doi.org/ 10.1002/19970504NT4

Orr PT, Jones GJ (1998) Relationship between microcystin production and cell division rates in nitrogen-limited Microcystis aeruginosa cultures. Limnol Oceanogr 43:1604-1614. https://doi.org/10.4319/ lo.1998.43.7.1604 
Oshima Y (1995) Postcolumn derivatization liquid chromatographic method for paralytic shellfish toxins. J AOAC Int:528-532. https://doi.org/10.1093/jaoac/78.2.528

Paerl HW, Huisman J (2009) Climate change: a catalyst for global expansion of harmful cyanobacterial blooms. Environ Microbiol Rep 1:27-37. https://doi.org/10.1111/j.1758-2229.2008.00004.x

Paerl HW, Paul VJ (2012) Climate change: links to global expansion of harmful cyanobacteria. Water Res 46:1349-1363. https://doi.org/ 10.1016/j.watres.2011.08.002

Paerl HW, Gardner WS, Havens KE, Joyner AR, McCarthy MJ, Newell SE, Qin B, Scott JT (2016) Mitigating cyanobacterial harmful algal blooms in aquatic ecosystems impacted by climate change and anthropogenic nutrients. Harmful Algae 54:213-222. https://doi.org/ 10.1016/j.hal.2015.09.009

Pinowska A, Stevenson RJ, Sickman JO, et al (2007) Integrated interpretation of survey for determining nutrient thresholds for macroalgae in Florida Springs. Laboratory experiments and disturbance study. https://yosemite.epa.gov/sab/sabproduct.nsf/ 4B3F72138829D3B9852576270067A54A/\$File/Comments+ from+Daryll+Joyner.pdf

Preußel K, Wessel G, Fastner J, Chorus I (2009) Response of cylindrospermopsin production and release in Aphanizomenon flos-aquae (Cyanobacteria) to varying light and temperature conditions. Harmful Algae 8:645-650. https://doi.org/10.1016/j.hal.2008. 10.009

Quebec Laboratory of Environment Testing, Montréal (2011) Manual of analytical methods. Environment Canada, Montreal

Roy-Lachapelle A (2016) Nouvelles stratégies pour l'analyse des cyanotoxines par spectrométrie de masse. Ph.D thesis. Univ. of Montreal. https://papyrus.bib.umontreal.ca/xmlui/handle/1866/ 13570

Seifert M, McGregor G, Eaglesham G, Wickramasinghe W, Shaw G (2007) First evidence for the production of cylindrospermopsin and deoxy-cylindrospermopsin by the freshwater benthic cyanobacterium, Lyngbya wollei (Farlow ex Gomont) Speziale and Dyck. Harmful Algae 6:73-80. https://doi.org/10.1016/j.hal.2006.07.001

Sivonen K (1990) Effects of light, temperature, nitrate, orthophosphate, and bacteria on growth of and hepatotoxin production by Oscillatoria agardhii strains. Appl Environ Microbiol 56:2658-2666
Sivonen K, Jones G (1999) Chapter 3, Cyanobacterial toxins. In: Chorus I, Bartram J (eds) Toxic cyanobacteria in water: a guide to their public health consequences, monitoring, and management. E \& FN Spon, London, pp 43-112

Smith ZJ, Martin RM, Wei B, Wilhelm S, Boyer G (2019) Spatial and temporal variation in paralytic shellfish toxin production by benthic Microseira (Lyngbya) wollei in a freshwater New York Lake. Toxins 11:44. https://doi.org/10.3390/toxins11010044

Stainton MP, Capel MJ, Armstrong FAJ (1977) The chemical analysis of fresh water. Miscellaneous special Publ. No25. Fisheries and Environment Canada second Ed. Fisheries and Marine Service, Freshwater Institute. Winnipeg, Manitoba. 166p.

Umehara A, Takahashi T, Komorita T, Orita R, Choi JW, Takenaka R, Mabuchi R, Park HD, Tsutsumi H (2017) Widespread dispersal and bio-accumulation of toxic microcystins in benthic marine ecosystems. Chemosphere 167:492-500. https://doi.org/10.1016/j. chemosphere.2016.10.029

Visser PM, Verspagen JMH, Sandrini G, Stal LJ, Matthijs HCP, Davis TW, Paerl HW, Huisman J (2016) How rising CO2 and global warming may stimulate harmful cyanobacterial blooms. Harmful Algae 54:145-159. https://doi.org/10.1016/j.hal.2015.12.006

Walls JT, Wyatt KH, Doll JC, et al (2018) Hot and toxic: Temperature regulates microcystin release from cyanobacteria. Sci.Total Environ. 610-611:786-795. https://doi.org/10.1016/j.scitotenv.2017.08.149

Yin Y, Winkelman JS, Langrehr HA (2000) Long term resource monitoring program procedures: aquatic vegetation monitoring. U.S. Geological Survey, Upper Midwest Environmental Sciences Center, La Crosse

Zamyadi A, MacLeod SL, Fan Y et al (2012) Toxic cyanobacterial breakthrough and accumulation in a drinking water plant: a monitoring and treatment challenge. Water Res 46:1511-1523. https://doi.org/ 10.1016/j.watres.2011.11.012

Zervou S-K, Christophoridis C, Kaloudis T, Triantis TM, Hiskia A (2017) New SPE-LC-MS/MS method for simultaneous determination of multi-class cyanobacterial and algal toxins. J Hazard Mater 323:56-66. https://doi.org/10.1016/j.jhazmat.2016.07.020

Publisher's note Springer Nature remains neutral with regard to jurisdictional claims in published maps and institutional affiliations. 